\title{
A STUDYOF TRADITIONAL MORTUARY PRACTICES OF THE JAINTIAS OF MEGHALAYA, INDIA
}

\author{
Akoijam Milan Meitei \& Queenbala Marak
}

North-Eastern Hill University, Shillong, Meghalaya, India

\begin{abstract}
The functions of megaliths are many, some of which continue today among a few communities across the world. This paper discusses the traditional mortuary practices of the Jaintia tribe of Meghalaya, India in connection to dolmen, dolmeinoid cists, cairns etc.

Jaintias are one of the tribes of northeast India practicing megalithic traditions in various ways - in commemoration of an event or a person, as an integral part of burial rites, and in various religious contexts. Menhirs, dolmens, cists, dolmeinoid cists, cairns, capstones etc. are found in different locations in Jaintia Hills. Among these, deposition of the deceased's bones in dolmens or dolmeinoid cists is one of the main practices which continue till today.

In this paper we will discuss the different practices connected to these burials, the reasons thereof, and the changes that have taken place. While comparing the practices prevalent in two locations at a distance of $36 \mathrm{kms}$ (inhabited by the same people), we conclude that spatial distance within the same group aids in an intra-group difference.
\end{abstract}

Keywords: megalith, mortuary practices, Jaintias, Niamtre, Christianity.

\section{INTRODUCTION}

The presence of megalithic structures in Jaintia Hills was revealed as early as 1844 by Henry Yule to the academic world. A number of British administrators thereafter gave ethnographic information on megaliths of the region [Yule (1844), Godwin-Austen (1872), Clarke (1874), Gurdon (2012 [1907]), Hutton (1926, 1929)]. These administrators collected information as a part of their administrative duties, and were not trained researchers. It is noteworthy that two local researchers, namely, David Roy and Hamlet Bareh did extensive works on the megaliths of Khasi-Jaintia Hills (Roy 1963, Bareh1967). Interestingly, in academic circles, the megaliths of Jaintia Hills have always been studied as a part of the greater Khasi Hills megaliths.

The use of megalithic tombs (Fagan 1996) and crude stones in mortuary practices are reported since Neolithic times. Such mortuary structures have given impressive and revealing evidences about the ancient way of life (Choudhury 2004). Additionally, burial and mortuary practices can foster the integration of individuals and related households that form social groups and the continuity of these groups through time (Adams and King 2010).

In a pre-industrial society, the dead are central to the production of social order. They are transformed into ancestors through these mortuary practices (Porter 2002). In some tribal societies, this practice still continues in some form or the other. The traditional rituals of death stand at the centre of their social life. They are characterized by widely shared and explicit norms of social behaviour, in general, and of mortuary rituals in particular (Abramovitch 2001).

In some cultures mortuary rituals involve multiple burials and reburials or cremations and re-cremations in which the deceased is figuratively and literally deconstructed and reconstructed (Ingham 2001). In the case of India, a section of Karbis of Assam (Bezbaruah 2003), few tribes of central India (Furer-Haimendorf 1945), Nagas of Manipur (Singh 1985, Devi 2011) and Nagas of Nagaland (Jamir 1998, Jamir 2004) are also seen using megaliths in mortuary practices. The Garo style of using megaliths is found in a modified form - they erect carved wooden posts called kima in honour of the dead but not the stone structure (Playfair1998 [1909], Marak 2012a).

Use of megaliths in mortuary practices is reported to be a world phenomenon in preliterate societies. In this, associated rituals and offer of food to the deceased ancestors are the chief practices. Over time, such traditional practices have undergone transformation due to change in their religious beliefs. Some factors which have brought in such changes include adoption of organized religion such as Christianity, introduction of scientific education and modernization. Despite, these factors of change, traditional mortuary practices are still seen in few tribal societies across the world in one form or the other. Thus, the use of megaliths for mortuary purposes by traditional believers among the Jaintias, the Niamtre, is one of the salient features seen in Jaintia Hills, Meghalaya. This paper makes a comparative study of megaliths related to mortuary practices in two Jaintia villages. The data for this paper was collected from an ethnoarchaeological study conducted in the villages of Shanpung and Nartiang, in the months of December 2012 and January 2014 respectively (Figure 1). 


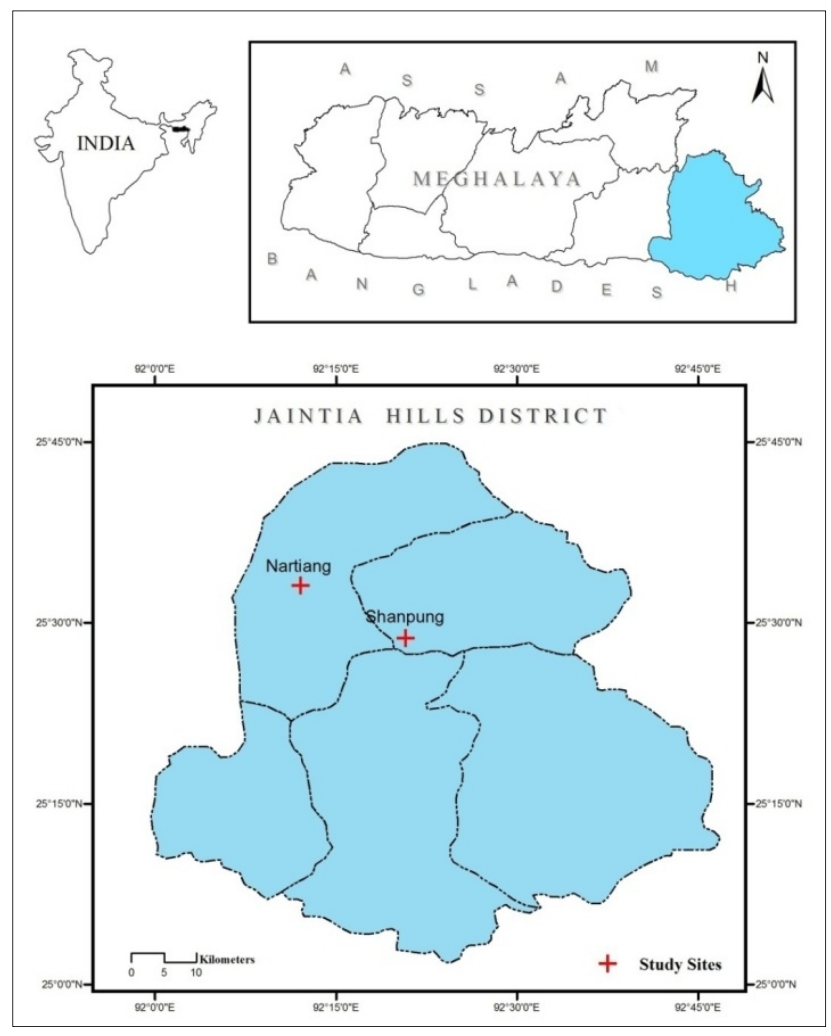

Figure 1: Map of Jaintia Hills District showing the location of the two studied villages

\section{NARTIANG AND SHANPUNG: THE VILLAGES UNDER STUDY}

The present paper studies the mortuary practices of the Jaintias living in two villages - Nartiang and Shanpung. Both the villages are located in Jaintia Hills District (Figure 1), separated by a distance of $36 \mathrm{~km}$. Nartiang is located towards the east of Shillong (the capital of the state of Meghalaya), and north of Jowai (the district headquarter of Jaintia Hills District) at a distance of $65 \mathrm{~km}$ and 27 $\mathrm{km}$ respectively. Shanpung is located towards the east of Shillong at a distance of $86 \mathrm{~km}$ and northeast of Jowai town at a distance of $21 \mathrm{~km}$.

Jaintias are a matrilineal Mon-Khmer speaking group of people inhabiting the eastern part of Meghalaya, a hilly state of north-east India. They speak Mon-Khmer of the Austro-Asiatic language family (Rao 1991). They are traditionally megalithic users and are well known for erecting megaliths, and for their matrilineal descent. They are known by different names, such as Pnar and Synteng. The traditional religion of the Jaintias is Niamtre which is a belief in ancestors, spirit worship, and in a number of gods and goddesses. These gods and goddesses have different names and roles. Female deities are conceived as agents of familial and social well-being and collective economic endeavours, whereas male deities are connected with state administration, social activities and territorial defence (Sen 2004). The supreme god, U Blai Nongtaw is also represented by goddess Ka Blai Synshar, thus reiter- ating that the supreme power is beyond gender (Marak 2012b).

Nartiang, in ancient times, is said to have had plenty of iron ore. Iron ore was extracted from the soil of the village. It had one house/school for blacksmithy referred as 'shlem' in local dialect (shlem = industry in Pnar dialect). At this place they manufactured iron implements like knife, dao, axe, spade etc. which were needed in their day to day lives. According to popular lore, one day some blacksmiths went to the field to extract iron ore. Suddenly they found one very hard piece of iron. When they were trying to dig it out, an unnatural sound was heard which reverberated as 'ting-ting, ting-ting'. From this, the village came to be named 'Nartiang' ( $U N a r=$ iron in Pnar dialect, tiang $=$ ting). The original inhabitants of the Nartiang village were the matrilineal clan members of the Dhar, Dkhar, Lamare, Symblai and Pale clans. Other clan members later settled in the village. At present, the village has seven localities - Lum Majar, Lum Kyalyndoh, Lum Bisary, Wah Lasut, Khlieh Shlem, Wah Shlem and Poh Iaw.

On the other hand, in local Pnar dialect 'Shanpung' means 'basket lake', so named since the village was earlier surrounded by water bodies in all direction. At present, it is still surrounded by small lakes such as Moolishah, Umiuriam, Kaksang, Umrangnah, and Yillip. The village of Shanpung consists of nine small localities namely Moolisang, Khliehmuchut, Moosyiem, Coira, Mission, Thohlakymah, Lummuchai, Lumrangnah, and Lumnengshnong. The village is inhabited by 12 clans (khaarnor) - Sungoh, Dhar, Phyllei, Lamare, Swan, Langsteng, Langbang, Sutnga, Law, Passah, Lapasam and Kamar. It is said that Row Sungoh from the Sungoh clan first settled in the village thousands of years back.

In Shanpung, some inhabitants have embraced Christianity, while in the case of Nartiang, all inhabitants continue to follow traditional religion Niamtre. In both the study areas, megalithic structures like menhirs, alignments, cairns, dolmens, capstones, and others are found, each of these stones having different functions and purposes. However in this paper only the megaliths which are used in mortuary practices are discussed. Traditional Niamtre followers of the two villages still practice mortuary rites in relation to megaliths. However, over time, some changes and modifications are seen in these practices. This is related with the socio-cultural and religious beliefs of the local villagers. More importantly their present-day belief is influenced by external forces like Christianity, modern education and modernization.

\section{DESCRIPTION OF MEGALITHS RELATED TO MORTUARY PRACTICE}

\section{Nartiang Village}

In Nartiang village, all megaliths connected to mortuary practices lie in a sacred place called Kpep. There is no specific pattern of laying these bone crypts. Rather, as the investigators have witnessed, these megaliths are morphologically different from each other, in terms of size and arrangement. Therefore, a common terminology for these 
is not possible. Each of the group of stones follow different pattern. The first type is a stone enclosure (Figure 2) which consists of a group of miniature megaliths arranged in a square. Inside this square is a circular dolmen. There is a passage chamber (entrance) leading to the stone enclosure. The second is a stone enclosure (Figure 3) within which also lies a group of dolmens. The third type (Figure 4 ) is a rectangular enclosure within which is a dolmen.

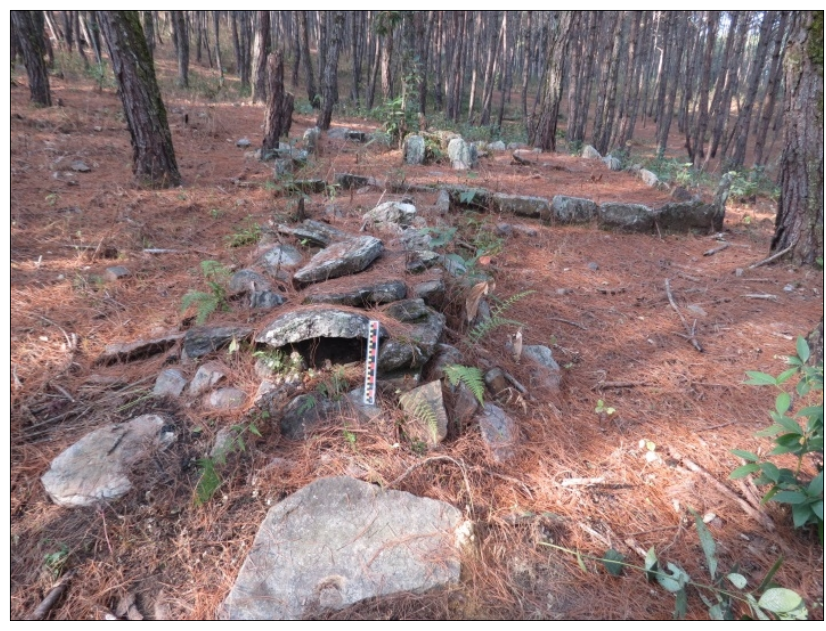

Figure 2: A stone enclosure with a dolmen and a passage entrance.

However, despite the morphological variation in size and dimension, a common pattern emerges - that of a stone enclosure in a polygonal or circular shape. In each of these groups of stones there is a territorial mark or boundary representing each clan of the village. Inside this stone circles, there is one or more main bone depositing stones (i.e., dolmens) where all bones of the clans are kept. These megalithic structures are thus in the form of a dolmen or dolmens of various pattern within a stone enclosure (either polygonal or circular). In terms of function, they are all used for deposition of bones of the deceased.

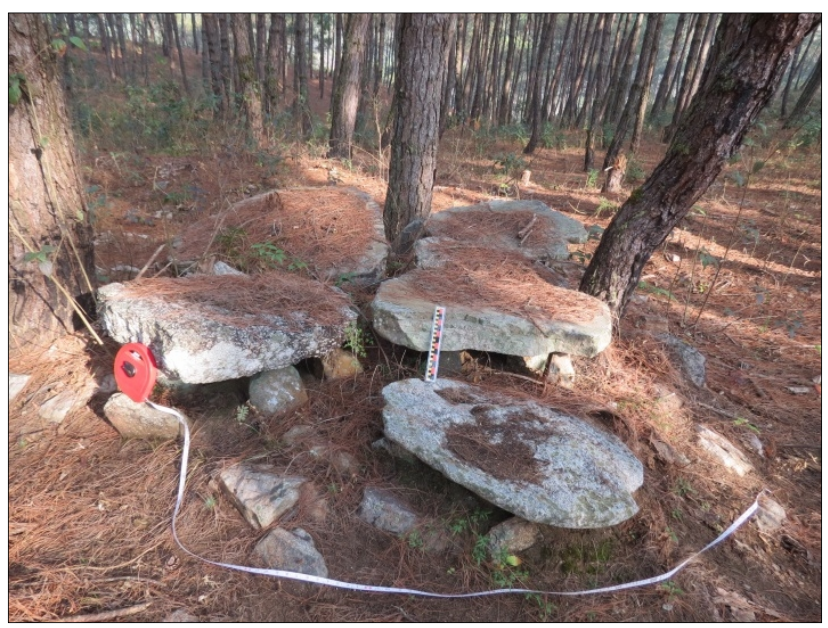

Figure 3: A stone enclosure with a group of dolmens inside.
The burial place of the village (Kpep) is however considered a sacred place. The boundary of the burial stones is made by rows of stones in patterns like square, rectangle, circle etc. to protect the main stone (dolmen) from further harm. The main depositing burial stones are placed in the middle of the stone circle. Most of the burial stones of the sacred place, over time, are found to be scattered - these are then again covered by soil up to some height to safeguard them from further harm.

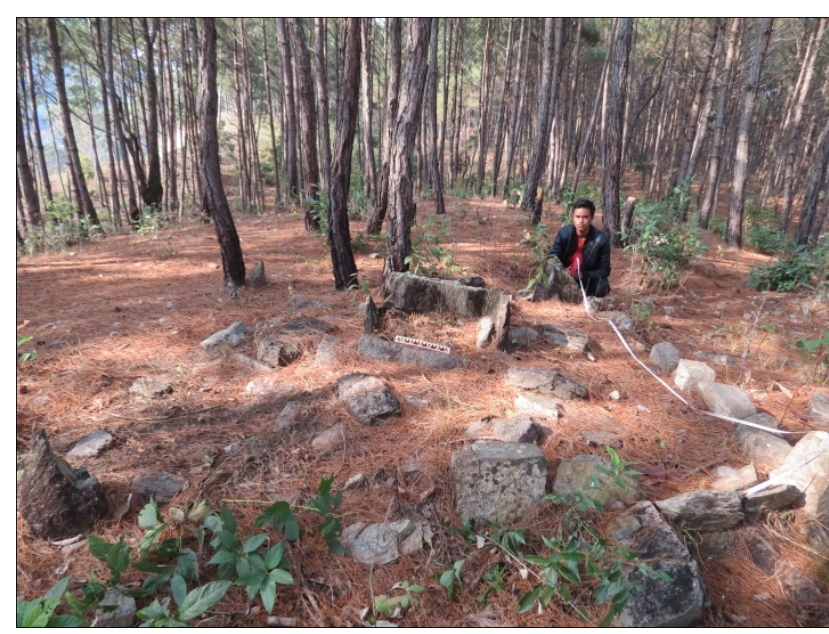

Figure 4: A rectangular enclosure with a dolmen inside.

\section{Shanpung Village}

In village Shanpung too, a sacred place (Kpep) exists where bones of the deceased are deposited. However, unlike Nartiang, there are only three specific types of stones, which are functionally and morphologically different from each other, and hence easier to give a nomenclature. These are: a) chadphur or stone circle, b) moowasa or cairns and c) mookylliam or dolmen.

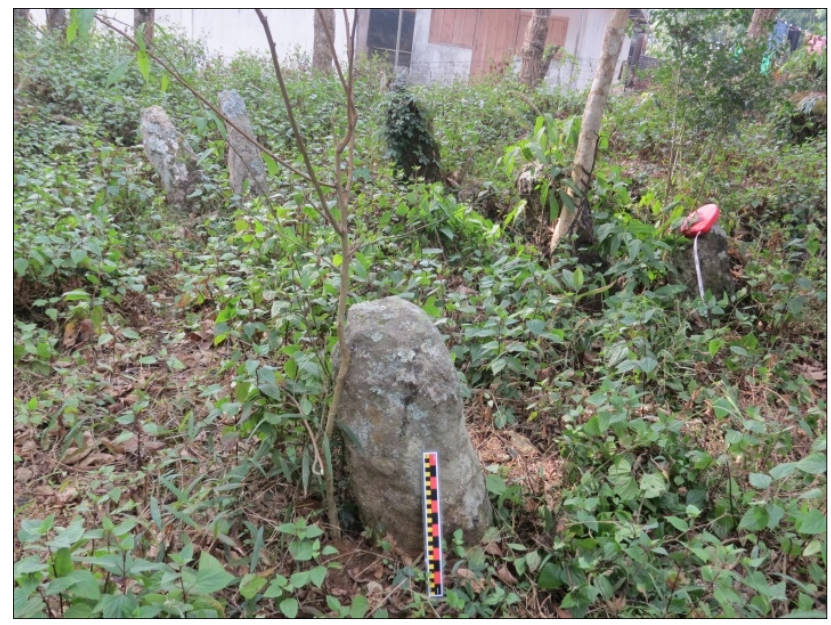

Figure 5: Chadphur or stone circle in Shangpung village.

Chadphur (stone circle) is a circle of menhirs (Figure 5). It consists of small pillars arranged in a circular fashion to form a ceremonial ring. It consists of six or seven 
menhirs making a circle. The chadphur in the village is common for all the clans.

Moowasa is a pile of stones (cairns), often in a conical form (Figure 6). These are therefore heaped up mounds of stone rubble. The moowasa stones are placed in a conical shape leaving a small hollow or space in the middle of the stone with an opening lid (mootymoh) on the top. It is used for keeping and depositing the bones of the deceased temporarily. It thus consists of two parts - a) mooshan or cairns, and b) mootymoh or capstone.

Mooshan are heaped up mounds of stone rubble. They consist of a heap of stones or rubbles of smaller stones by piling up the stones one above the other. Mooshan is the foundation or base or pillar of the mootymoh stone and it supports and helps to keep the mootymoh stone on top. On the same day of the cremation, the deceased's bones are deposited and then mooshan stones are placed to cover the bones. To protect the deceased's bones from scavenging animals, they cover it with mootymoh on top of the mooshan.

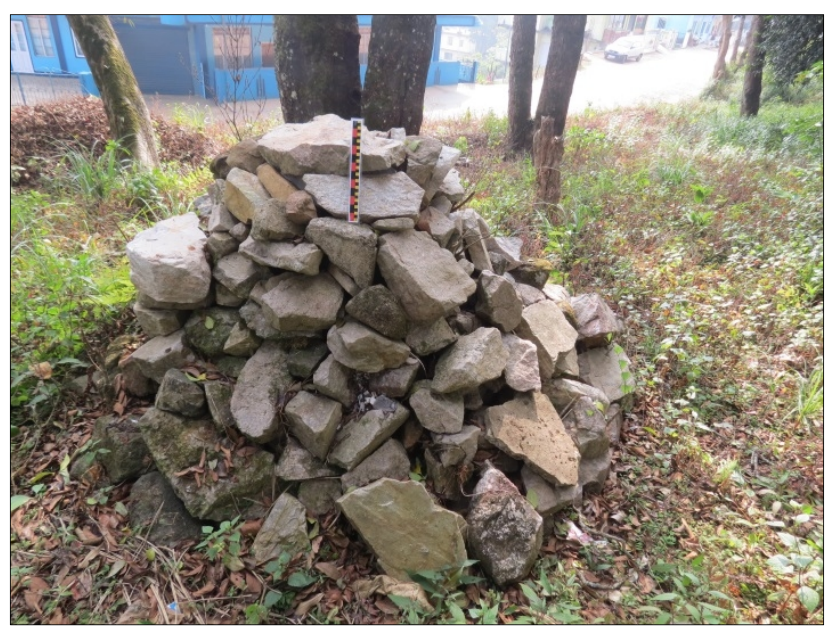

Figure 6: Moowasa or cairn in Shangpung village

Mootymoh or capstone is a circular flat slab. It is kept on top of the mooshan stone and is the topmost part of the moowasa stone. It is used to cover the small hollow space present in the moowasa stone which is used to keep the deceased's bones. Unlike mooshan stone, the mootymoh stone is selected and taken out from the sacred place of the village (Kpep). The eldest man of the clan and family (iing) takes it out and places the mootymoh stone whenever it is required. Both the deposition of mooshan and mootymoh take place only when someone dies.

Mookylliam or dolmen is a small stone-built coffinlike box or ossuary to hold the bones of the dead (Figure 7). These are box-like stone chambers. Many times these chambers are opened periodically by removing one of the vertical stones for depositing ashes or bones of deceased ancestors. Many other times they stand alone or in association with menhirs or dolmens.

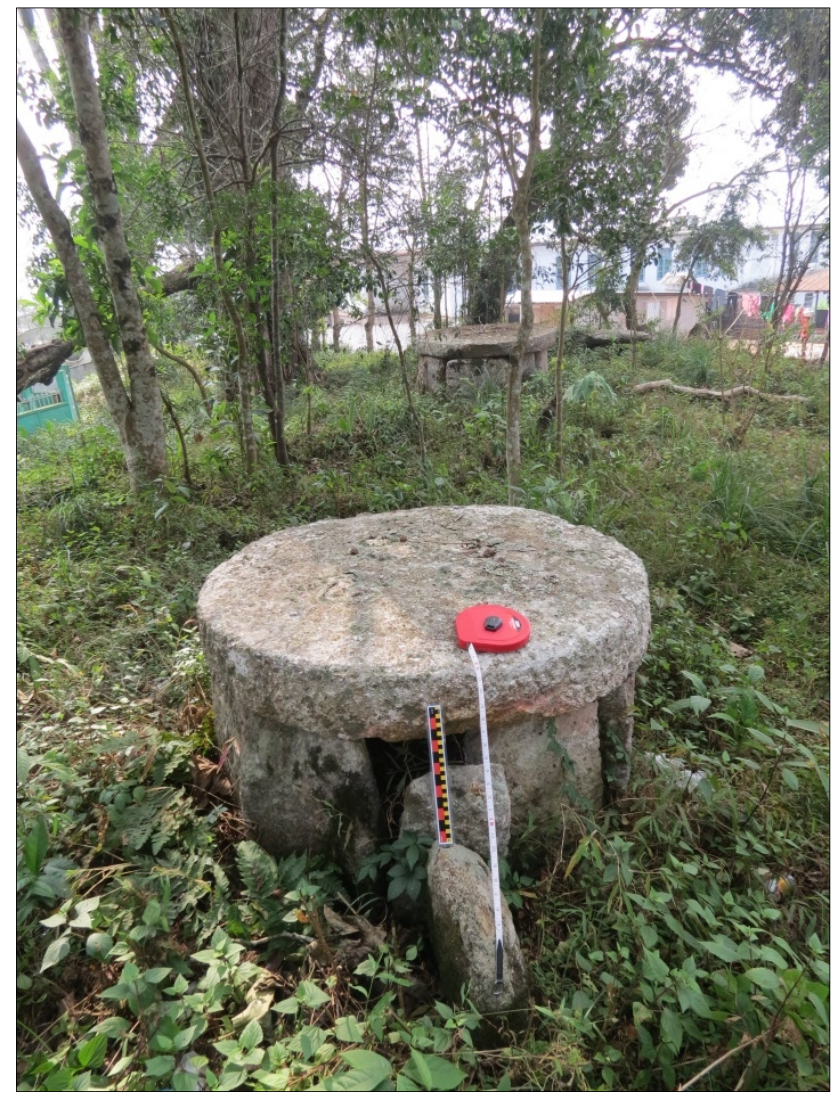

Figure 7: A mookylliam or dolmen in Shanpung village

Mookylliam is circular in shape and surrounded on all sides by vertically erected stones with a big slab of stone at the top. Just like the moowasa, each clan has their own respective mookylliam stone and it has two parts as well: i) mooshan, the vertically erected stone and ii) mootimoh, the big slab placed atop the mooshan stone. Here unlike moowasa, mooshan stones are permanently placed and the size of the mootimoh in mookylliam is much bigger than mootimoh of moowasa. The mookylliam stone is the permanent resting place for keeping all the ancestral bones of each clan. In each of the mookylliam stones, there is an entrance which is covered by another smaller removable stone; alternatively, a small hole is present for placing the bones.

\section{TRADITIONAL MORTUARY PRACTICES}

The contemporary Niamtre Jaintias of Jaintia Hills continue one of its ancient mortuary practices, i.e., deposition of bones in the stone structure. Traditionally, Jaintias cremate the dead. When the cremation is over, small pieces of bones or ashes of the deceased are collected. These are placed in the temporary depositing crude stone structures/places, and then transferred to their permanent clan stones. This becomes the symbol of unity for the souls of all the deceased. Thus, these stones are related to the post funerary/cremation rituals of the Jaintias and are an important part of their socio-cultural beliefs and behaviour. 


\section{Nartiang village}

In Nartiang, after cremation they first carve out a small hole in a tree near the cremation site. The hole of the tree is at a height so that it can be protected from animals and accidental nuisance activities. Small pieces of bones or ashes of the dead person are then collected, and placed inside the small hole made on the trunk of the tree. Usually, the tree selected for this rite is owned by the clan; at other times, it can be a commonly owned tree (by the whole village), but selected by the deceased's family for the purpose. After two or three years, the head of the family (only a man) will take it out and transfer it permanently to the clan burial stone (dolmen) which lie in the Kpep. This dolmen already houses the bones of the dead ancestors of the same clan. For the transference of the newly deceased, the family invites relatives to bear witness and to share in the happiness of reunion of the bones of the deceased with those of the ancestors.

In present day Nartiang, however, a change is witnessed. Transference of the deceased's bones has stopped among majority of the villagers (and clan members) as modern day Jaintias now believe it to be an ancient superstition. The accompanying rituals and prayers while transferring the bones into the Kpep have been relegated to the past. The present descendents no longer remember the hymns which were an important part of the ritual while depositing the bones of the deceased. Today, their traditional procedure of transference of bones from tree to the permanent megalithic structure (dolmen) is very rarely seen. Many prefer to keep the bones inside the hole of the tree forever after cremation. Nevertheless, the Kpep is still considered a sacred place.

The mortuary stones in the Kpep show the demarcation of a particular territory for each clan. This clearly shows the concept of identity, integrity and unity of the clan members of the village during their lifetime as well as afterlife. The boundary stone around the main dolmen in the form of square/circle/rectangle is seen erected to protect the dolmen itself, and the bones deposited within from further harm. This is important since according to Jaintia concept of life and death, this is the only place where all the deceased belonging to a specific clan meet together. The spirits of clan members stay in his/her particular clan even after death in the form of the soul. It is in the Kpep that all the deceased family and clan members from villages far and wide (since many would have shifted to other villages during their lifetime due to marital alliances) would once again meet and stay together forever.

\section{Shanpung village}

In Shanpung village, the traditional mortuary practices are seen to be more systematic and it is still in practice. Here too, all the bone crypts lie in the Kpep. This is located in a small hillock in the village. Each of the clans has their own respective clan burial structures. There are three types of stones found in the Kpep as mentioned earlier chadphur, moowasa and mookylliam. They differ not only in morphology, but also in function.
Chadphur is a common stone (megalithic structure) where ritual is done before depositing the deceased's bones. In the past, the chadphur was the first place of performance of a ritual conducted on the same day of the cremation before the bones were transferred to the moowasa (cairns). As time passed, the importance of chadphur as a part of funerary and the post-funerary rituals was lost.

Moowasa, today, is thus the first place of storing, keeping, and depositing the deceased's bones, though only temporarily. Every clan of the village has its own moowasa stone, and all the deceased members of a clan (their bones) are kept in their specific moowasa. Some of the moowasa are placed against a tree for support, others in open spaces, and still others against a brick wall. Its dimensions differ from clan to clan. After cremation, bones are collected and deposited in the moowasa stone (cairn) on the same day. The small pieces of bones are carried by an elderly man of the same clan from the place of cremation. Other elderly members of the family bring four or five pieces of stone (mooshan stones) to cover the bones. Offering of food and other items to the deceased are done only at this stone.

Interestingly, the bones of those persons who reportedly "made bad remark" (i.e., lived a life not in conformity with clan regulations etc.) during their lifetime, are not mixed together with other deceased family members' and clan members' bones. Even if they are kept in the same moowasa stone, they are kept separately away or behind the main moowasa stone. This is a temporary place for bones, but for those who "made bad remarks" during their lifetime, it is the only and permanent place.

It is believed that the transfer of bones from moowasa (cairn) to mookylliam stone (dolmen) will lead to rebirth of the soul. This is the final and permanent residing place for all the bones of the deceased of each clan. Every year in the month of June, bones from moowasa (cairn) are collected and transferred in mookylliam (dolmen). It is practiced by every clan of the village and conducted with or without the kadaw (priest), by elderly male members.

The offering of ritual items for the deceased in both the villages is more or less the same. They offer beedi, rice, wine, areca nut and betel leaf, coins, flowers and other eatable items, together with some other objects which were used by the deceased during his or her lifetime. This is a respect shown to the dead and a duty of the living family members. It is believed that it will keep the deceased's soul in peace and make him/her happy in the after world. All friends, relatives and family members of the deceased pray to the Supreme God for the safe journey of the soul when offering beedi, rice, wine, areca nut and leaf, coins, flower, and other eatable items. The offering here is similar to the offering made at the first mortuary ritual of the Khasis, but among the Khasis, transference of bones follows a series of sacrifices (of bull, cow, pig, goat, etc.) to reach the last stage of burial stone (mawniam) along with traditional dance (Roy 1963). It is likely that traditionally the Jaintias also must have sacri- 
ficed a number of animals, but today due to cost economics as well as changes taking place, it is no longer seen.

\section{DISCUSSION}

The practice of mortuary rituals and deposition of bones among the Jaintias is associated with their traditional religion, Niamtre. The origin of Jaintia religion is animistic in nature. Their religious beliefs state that the dead ancestors turn into a spirit (Bareh 1967). The connections between the living and the dead can be extended to indicate an actual presence of the dead within the lives of the living and the deceased as active agents in the lives of the living (Adams and King 2010).

In Khasi-Jaintia Hills of north-east India, the deposition and preservation of the deceased remains are considered a sign of respect, a part of matrilineal kinship solidarity, and social merit (Rao 1991, Mawlong 2004, Sen 2004, Marak 2012b). In these villages, there is a belief that there exists a continuity and interconnectedness between the living and the deceased ancestors in the after world where the deceased live a similar life to the life on earth as a spirit. In mortuary ceremonies, many offer food, drink, clothes etc. which the deceased liked or which once belonged to them. They believe that ancestors in the form of spirit thrive around them while watching over them. Those who do not care for the deceased will attract punishments like sickness, accident, poverty etc. Those who fulfil the traditional norms will be blessed with social merit, fertility, good health, prosperity etc.

The important burial traditions and ritual practices indicate the association or connection between the living and deceased ancestors (Hodder and Cessford 2004). Burial and mortuary practices can foster the integration of individuals and related households that form social groups and the continuity of these groups through time (Adams and King 2010). In many traditional cultures, however, death rituals stand at the centre of social life. Wandering spirits for whom no rites were performed may act as hungry ghosts. Illness, misfortune and associated healing rituals are often attempts to incorporate these lost souls (Abramovitch 2001). Thus, mortuary rituals, in honour of the ancestors, and the stones have a strong sense of connectivity with the living descendents.

Ethnographically, it is believed that ancestors are essential to the well-being of the living descendents. This connection can be manifested in beliefs that the dead can harm or cause misfortune to the living if certain rituals were not performed or they are not satisfied. Thus, the deceased can be viewed as guiding the behaviour of the living. This illustrates the continual importance of deceased ancestors and social memory to their descendants, i.e., in the lives of the living. The ancestral spirits and the living descendents are connected by an unseen bond. They become the link between the ancestral spirit of the family or clan and the living descendants.

Therefore, in the Kpep, all the deceased ancestors of the village will meet, whereas in their clan or family's bone crypt, all the clan or family members meet and stay together. This is the only residing place of all the souls of the deceased in afterlife. The Jaintias also consider human flesh as soil; and that it will turn into soil of the earth after death. Thus, as a duty, they perform the ritual of deposition of the deceased's bones, transference, and placing of the bones in a permanent location under protection for the satisfaction of the souls of the deceased.

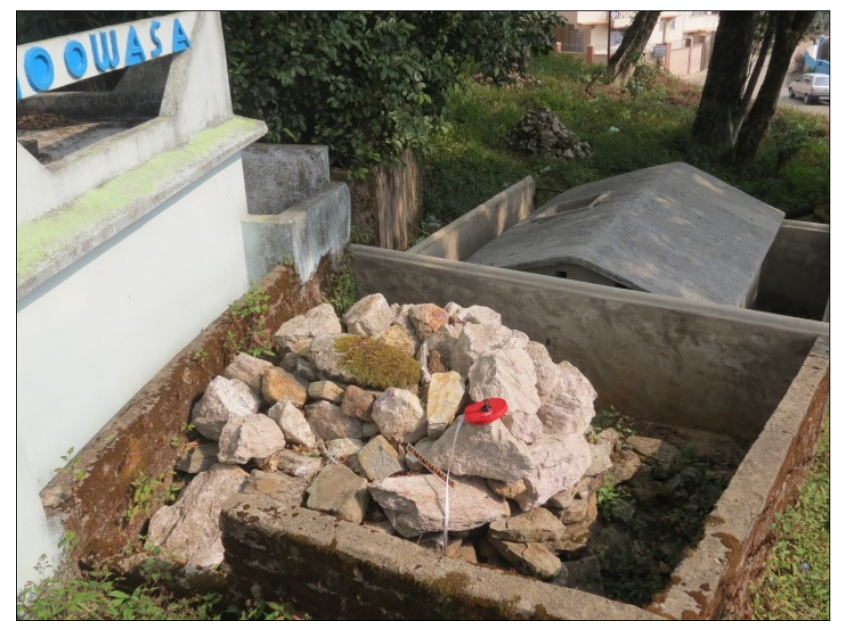

Figure 8: Moowasa or cairn surrounded by modern structure in Shanpung village

Changes were witnessed in both the villages. In Nartiang, only the sacred place, Kpep, exists along with unused mortuary stones. There is no record of transference of bones of the deceased in the recent past. This traditional practice is lost from the minds of the people. Now they place the bones of the deceased permanently inside the tree trunk. Thus, the mortuary stones inside the Kрер are scattered and broken down. In Shanpung, the first place of mortuary ritual, chadphur (stone circle), is no more used and has lost its cultural meaning. Presently, it is seen that for some clans, cement and mortar is used as boundary markers of the cairn stones inside the Kpep (Figure 8). However, the transference of bones from cairn stones to dolmens is strongly practiced.

Though there is no record of erection of new megaliths in the region, from interviews conducted it was learnt that in the past very simple tools (iron implements) could have been used to construct these structures. This is supported by the existence of traditional iron factories in the region. However, rich lore exists about how the large structures were transported from one place to another after a series of rituals and accompanying prayers. Clarke (1874), while discussing the megaliths of the neighbouring Khasis, mentions the use of the simplest and most direct mechanical means as well.

Religion plays an important role in ritual beliefs and practices of both the studied villages. Niamtre Jaintias generally practice their traditional rituals. Due to proselytisation, a large number of people converted to Christianity as early as the middle of the $19^{\text {th }}$ century. Today, there are two religions being practiced in this hill area - traditional Niamtre and Christianity. Niamtre followers continue their ancestral practices, especially the mortuary rituals. 
Christian converts no longer use mortuary stones, and their religious traditions have been relegated to the past. They now adopt Christian rituals in their mortuary practices. Thus, many lithic structures have been relegated to the background after the coming of Christianity (Marak and Jangkhomang 2012).

\section{CONCLUSION}

A study into the mortuary practices of the two villages reveals differences in the morphological and functional elements. However, the internal meaning for deposition of the deceased's bones is the same, despite minor differences in morphology. Presently in Nartiang, the deceased's bones are kept only in the tree trunk permanently. In Shanpung, there is no ritual in the chadphur stone; additionally they have started using modern materials such as cement and mortar for making the boundary of the moowasa stone. The traditional mortuary practices are still strongly preserved even though the number of Christians has increased over the years.

The bone repositories are still kept preserved, and many are still in use by the Niamtre Jaintias. The deposition of bones and performance of its accompanying rituals are the duty of the deceased's descendents and it is performed for the well-being of the deceased's new journey into the after world. It is believed that this process will bring prosperity to the descendents, and prevent the family/clan from harm and evil. This becomes the link between the ancestral souls of the family/clan and the living descendents. Though the family is the primary social unit and the clan is the secondary social unit, the clan plays a larger role in their lives, and remains the only social unit after death. However, it is only the Niamtre Jaintias who follow their traditional mortuary behaviour.

This paper shows the relationship between the living descendents and deceased ancestors. Again, interestingly, it is seen that culture is dynamic and regional variations exists even within the same group of people. Thus, due to a geographical space existent between two contemporary Jaintias discussed in this paper, their stone mortuary practices differ, but interestingly their internal meanings remain the same.

\section{REFERENCES}

Abramovitch, H. 2001. Sociology of Death and Dying. In N. J. Smelser and P. B. Baltes (eds.), International Encyclopedia of the Social and Behavioral Sciences, pp. 3266-70. Berlin: Palo Alto.

Adams, R. L. and S. M. King. 2010. Residential Burial in Global Perspective. Archaeological Papers of the American Anthropological Association 20(1):1-16.

Bareh, H. 1967. History and Culture of the Khasi People. Calcutta: Naba Murdan Private Ltd.

Bezbaruah, D. 2003. Megalithic Ruins in Karbi Anglong District, Assam: A study in the Context of Karbi Culture. Unpublished Ph.D. thesis, Gauhati University, Guwahati.

Choudhury, K. 2004. The Megalithic and their associated remains in Dimoria area of Kamrup District, Assam. Unpublished Ph.D. thesis, Gauhati University, Guwahati.
Clarke, C. B. 1874. Stone Monuments of the Khasi Hills. Journal of Anthropological Institute 3(3): 48-93.

Devi, P. B. 2011. The Megalithic Culture of Manipur. Delhi: Agam Kala Prakashan.

Fagan, B. M. 1996. Oxford Companion to Archaeology. London: Oxford University Press.

Furer-Haimendorf, C. V. 1945. The Problem of Megalithic Cultures in Middle India. Man in India 26(2): 73-90.

Godwin-Austen, H. H. 1872. The Stone Monuments of the Khasi Hill Tribes. Journal of the Anthropological Institute 1(2): $122-43$

Gurdon, P. R. T. 1907. The Khasis. Delhi: Cosmo Publication.

Hodder, I. and C. Cessford.2004. Daily Practice and Social Memory at Çatalhoyuk. American Antiquity 69: 17-40.

Hutton, J.H. 1926. Some Megalithic work in the Jaintia Hills. Journal of Asiatic Society of Bengal 22(6): 333-46.

Hutton, J. H. 1929. Assam Megaliths. Antiquity 3: 324-38.

Ingham, J. M. 2001. Psychological Anthropology. In N. J. Smelser and P. B. Baltes (eds.), International Encyclopedia of the Social and Behavioral Sciences, pp.12349-55. Berlin: Palo Alto.

Jamir, T. 2004. Megaliths of Nagaland: Reflections of Material Milieu and Social Values. In M. Momin and C. A. Mawlong (eds.), Economy in North-east India Vol. 1, pp. 105117. New Delhi: Regency Publications.

Jamir, W. 1998.Megaliths in Nagaland. Purattatva 28: 104-10.

Marak, Q. 2012a. Megaliths of Northeast India. In T.B. Subba (ed.), Anthropology of Northeast India, pp. 34-52. New Delhi: Orient Longman Private Limited.

Marak, Q. 2012b. Megaliths, Types, and Its Living Traditions among the Jaintias of Northeastern India. Journal of IndoPacific Archaeology 32: 45-53.

Marak, Q. and Jangkhomang. 2012. Megaliths, Matriliny, and Living Practices: A Study of the Jaintia Megalithic Tradition in Meghalaya. Indian Anthropologist 42(2): 67-82.

Mawlong, C. A. 2004. Megaliths and Social Formation in Khasi-Jaintia Hills. In M. Momin and C. A. Mawlong (eds.), Society and Economy in North-east India Vol. 1, pp. 35-57. New Delhi: Regency Publications.

Playfair, A. 1998(1909). The Garo. Delhi: Spectrum Publications.

Porter, A. 2002. The dynamics of Death: Ancestors, Pastoralism, and the origins of a Third-Millennium city in Syria. Bulletin of the American School of Oriental Research 325: 136.

Rao, S. N. 1991. Megalithic Practices among Khasis and Nagas of North-Eastern India. In J. P. Singh and G. Sengupta (eds.), Archaeology of North-Eastern India, pp. 106-24. New Delhi: Vikas Publishing House.

Roy, D. 1963. The Megalithic Culture of the Khasis. Anthropos 58(34): 520-56.

Sen, S. 2004. Khasi-Jaintia Folklore: Context, Discourse and History. National Support Folklore Centre, Chennai.

Singh, O. K. 1985. A Live Megalithic Culture in Manipur. In V. N. Misra and P. Bellwood (eds.), Recent Advances in Indo-Pacific Prehistory: Proceedings of the International Symposium held at Poona, December 19-21, 1978, pp. 491-96. New Delhi: Oxford \& IBH Publishing Company.

Yule, H. 1844. Notes on the Khasi Hills, and the people. Journal of the Asiatic Society of Bengal 13(152): 612-31. 